\title{
The Bank Lending Channel of Monetary Policy Transmission: A Dynamic Bank-level Panel Data Analysis on Tanzania
}

\author{
Wilfred E. N. Mbowe ${ }^{* 1}$ \\ ${ }^{1}$ Manager, Research Department, Bank of Tanzania, Tanzania \\ Correspondence: Wilfred E. N. Mbowe, Research Department, Bank of Tanzania, Mirambo Street, 11884 Dar es Salaam, \\ Tanzania.
}

Received: September 6, 2016

Accepted: December 9, $2016 \quad$ Available online: December 22, 2016

doi:10.11114/aef.v4i1.2097

URL: http://dx.doi.org/10.11114/aef.v4i1.2097

\begin{abstract}
This study uses dynamic panel data estimation models, employing annual bank-level data spanning the period 2001-2011, to empirically investigate whether or not changes in the monetary policy in Tanzania influence bank lending behaviour, i.e., existence of a bank lending channel (BLC). It also examines the distributional effects of the monetary policy on banks with different balance sheet characteristics and ownership structures.

The findings lend support to the hypotheses that, first: BLC operates in Tanzania, suggesting that bank loans are important channel through which monetary policy shocks are transmitted to the economy. The findings mirror the arguments that the banking sector still dominates the financial system in the country, whereas money, capital, and real estate markets are still at their infant stages. Banks account for about three-quarters of the financial sector's assets, reflecting their dominance of sources of funding. Meanwhile, about two-thirds of bank funding comes from private sector deposits, probably constraining banks in offsetting the decrease in funds from deposits by raising funds from other sources. Second, banks react asymmetrically to policy changes influenced by size, capital strength, and ownership structure. The lending channel is stronger through domestically-owned banks and privately-owned banks than it is with foreign-owned banks and public-owned banks. The reason is that, for foreign-owned banks, they could enhance their capital through raising of equity abroad and/or benefit from retained earnings; while for public-owned banks, it could be because they are not under pressure to make profit and, therefore, may opt not to cut-down their loans following a monetary policy shock.

The policy implications are that, in assessing the stance of the monetary policy, beside short-term interest rates, it is critical for the monetary authority to trace banks reaction to monetary policy changes as reflected in loan supply to the private sector. Such investigation should also factor in possible asymmetric responses by banks influenced by size, capitalization, as well as ownership structure.
\end{abstract}

Keywords: bank lending channel, financial development, econometric models, Tanzania

\section{Introduction}

\subsection{Background to the Study}

Studies, including those by King and Levin (1993a; 1993b), Demirguc and Maksimovic (1998), and Levin and Zervos (1998), underscore the importance of well-functioning financial markets in an economy. Such markets, not only support economic development, but also enhance the effectiveness of monetary policy because they provide a mechanism for mobilization and allocation of financial resources.

In the 1990s, as a follow up to the recommendations of the Presidential Commission of Enquiry, Tanzania embarked on a series of financial reforms as an effort to promote the development of a market-based financial sector. This was done as a strategy to turning around the deteriorating economy and accelerating economic growth. The strategy was kicked off by the Banking and Financial Institutions Act of 1991, which paved the way for entrance in the financial sector of private foreign and domestic investors and development of money markets. As a result of this, Tanzania's financial sector witnessed huge private sector investment, bringing with it a new financial landscape, as well as a new culture of

*Pension funds hold about $21 \%$ of total assets, whereas insurance sector and other remaining financial intermediaries hold $2 \%$ of the total assets each. 
doing business (Bank of Tanzania [BoT], 2011a). Moreover, the reforms have enhanced the role of banks as a major source of finance to support economic activity in the country. These developments have important implications on how macroeconomic stabilization policies, the monetary policy in particular, affect economic activities.

Monetary policy can influence economic activity in the short to medium term, through a number of channels, including the interest rate channel, the bank lending channel (BLC), the balance sheet channel, and the exchange rate channel. According to Montiel et al. (2012), the ability of a central bank to influence the economic activity through these transmission channels depends on the strength and reliability of the links between policy instruments that it controls and aggregate demand.

\subsection{Statement of the Problem and Objective of the Study}

Recently, the literature has stressed the importance of bank loans in the transmission mechanism for developing countries, mainly because the economies are dominated by many bank-dependent borrowers (Ramlogan, 2004). Also, Mishra et al. (2010) and Montiel et al. (2012) provide theoretical arguments as to why BLC might be more effective in less developed countries than other channels. The reasons are related to: first, undeveloped money markets, so that central banks are unable to conduct monetary policy through open market transactions in secondary markets. Second, equity and real estate markets tend to be small and illiquid, which weakens the asset price channel of monetary policy transmission. Third, interventions by central banks in the foreign exchange markets weaken the exchange rate channel. This may be the case for Tanzania where banks account for about three-quarters of the financial sector's assets, and a large part of production is by small businesses some of which are bank-dependent. Like in many other developing countries, markets for direct financing (e.g., the bond and stock markets) in Tanzania are still at an infant stage. However, to the extent that Tanzania undertook considerable financial reforms in the 1990s, it may have reduced the role of banks in the credit market, and thus, have limited the potency of BLC (Mishkin, 1995). Montiel et al (2012) argues that the effectiveness of BLC in Tanzania may as well be constrained by possible uncompetitive banking system. Knowing how the Bank of Tanzania (BoT)'s policy actions are transmitted to the rest of the economy through this channel would contribute to the efforts to enhance the effectiveness of the monetary policy.

This study seeks to enquire on two related research issues: role of monetary policy in influencing bank lending behaviour in Tanzania and the extent to which bank-level characteristics and ownership structure affect the effectiveness of the monetary policy. The aim is to investigate whether the bank lending channel (BLC) operates in Tanzania, including the distributional effects of the monetary policy on banks with different balance sheet characteristics and ownership structures. The hypotheses are that BLC exists in Tanzania, and that the strength of the channel is influenced by bank's size, balance sheet strength, and ownership structure.

After the introduction, section two presents facts on Tanzania's financial system structure, bank credit supply evolution, as well as challenges to the operation of the BLC in the country. Whereas section three surveys the literature on BLC, section four details the conceptual framework and modelling technique. The regression results and discussion are in section five, while section six winds up by summarizing the policy implications of the findings, as well as areas for further study.

\section{Stylized Facts on Tanzania's Financial System Structure and Bank Credit Supply}

\subsection{Policy Evolution, Money Market, and Financial Structures}

In Tanzania, bank credit supply has evolved over time depending on the socioeconomic policy of the government. Three broad phases can be identified from Tanzania Mainland's independence in 1961. These are the period before 1967; the state control period from 1967 through 1991; and the post financial liberalization period, 1991 to date. Generally, the period before independence through 1967 was characterized by a market-based bank credit supply. Since Tanzania's independence was preceded by massive capital flight and withdrawals from commercial banks - mainly driven by uncertainty about the independence government that would take over-BoT was established in 1965 to perform all the traditional central banking functions, including overseeing credit allocation on a competitive environment. However, BoT could not perform this function effectively following the proclamation of the Arusha Declaration in February 1967, which placed all major means of production and exchange under the control of the state. Controls were also imposed on bank credit supply.

These policy changes created an inflexible economic system that was characterized by monopolistic and heavily regulated production structures. Similarly, the financial system was made up of a few public institutions enjoying a high degree of monopoly in their areas of specialization or functional designation. Excessive government borrowing and interference, as well as lack of adequate supervision of financial institutions resulted in high accumulation of bad debts by banks. High levels of inflation contributed to the decline in real returns on formal financial assets and thus financial disintermediation. These, together with other macroeconomic instability called for the need to undertake comprehensive economic reforms as of 1986. These changes were backed by the International Monetary Fund (IMF) and the World 
Bank (WB) adjustment programmes, which set targets for various important macroeconomic indicators. Measures were undertaken in certain crucial areas, including imposition of ceiling on government financing, devaluation of the Tanzanian shilling to reflect prevailing market conditions, and structural measures to eliminate controls in the foreign exchange market. In 1991, the Banking and Financial Institutions Act (1991) was enacted and its implementation paved the way for the entrance in the financial sector by private foreign and domestic investors. Also, it allowed for the elimination of remaining financial controls, introduction of financial markets and the use of indirect instruments of monetary policy. Restructuring of insolvent and inefficient government-owned banks that characterized the banking system before 1993 enhanced their efficiency and competitiveness. These, together with the enactment of the Foreign Exchange Act in 1992 that permitted individuals to hold foreign currency and foreign exchange accounts at commercial banks, contributed to the increase in the customer base as well as quantity and quality of banking services.

Moreover, the Bank of Tanzania Act of 1995, which relieved the Bank of non-traditional central bank functions, gave it independence in formulating and implementing monetary policy. The primary objective of the monetary authority remained implementing monetary policy that ensures price stability for a balanced and sustainable economic growth. The open market operations (OMO), introduced in 1993/94, is the main policy instrument, which provides mechanism to achieve three main objectives: financing of fiscal deficits, liquidity management, and anchor of interest rate determination. Banks can access intraday and Lombard facilities which were introduced in 2003 and Repurchase agreement (REPO) that was introduced in 2007 as stand-by credit facilities to accommodate short-term liquidity obligations.

Meanwhile, the Bank's regulatory and supervisory roles have also been strengthened to complement the monetary policy. Since 2007, BoT has adopted a more risk-focused approach. In efforts to put in place a formal mechanism for sharing of credit information and reduce information asymmetry on borrowers, a databank and private credit reference bureaus were established since October 2012.

There is huge evidence to show that the comprehensive financial reforms implemented in the 1990s greatly contributed to the financial development observed in Tanzania today (Nord et al., 2009; Mbowe, 2010; and BoT, 2011a). Nonetheless, such financial development followed financial reforms with a considerable lag, implying a delayed structural shift. For example, while interest rates were liberalized in 1991 and entry of private banks was permitted in 1992, none began operations until 1994, and the banking system began to expand dramatically only after 1998. In 1998, Tanzania had 18 commercial banks with 178 branches, but by 2009 the number of commercial banks had increased to 31 with 407 branches. At the end of December 2010, the banking sector was composed of 42 banking institutions-consisting of 28 fully-fledged commercial banks and 14 financial institutions-with 473 branches country-wide (BoT, 2010). As the number of banking institutions increased to 48 at the end of 2011, the number of branches rose to 503 (BoT, 2011b).

As it was the case before financial reforms, the banking sector dominates the financial system although now with more banks compared with only three banks before the reforms. As at the end of 2011, the banking institutions accounted for about $75 \%$ of the total financial assets (BoT, 2011b). This situation points to a possibility of banks dominance in sources of funding, likely strengthening BLC. ${ }^{1}$ In terms of market share, $50.5 \%$ (or an average of $51 \%$ during the period 2007-2011) of banks' assets were foreign-owned. In 2011, the ownership structure of the banking sector was such that five institutions were majority state-owned and 43 were majority privately-owned. Twenty-five banking institutions were locally-owned and 23 were foreign-owned. Despite the increase in the number of banks, the banking sector has persistently been dominated by the same five largest banks. Meanwhile, the stock market is still undeveloped. ${ }^{2}$ The policy and structural changes, as well as dynamics in the money markets and bank ownership structures may have important implications on the efficacy of BLC in the country.

\section{Literature Survey}

\subsection{Theoretical Literature}

BLC is based on the view that banks play an important role in the financial system as an external source of financing for firms. Because of banks' special role, certain borrowers will highly depend on bank loans, and will not have access to credit markets unless they borrow from banks. Bernanke and Blinder (1988) propose a framework through which monetary policy can affect banks' portfolio behaviour. The framework presupposes that a monetary contraction raises the interest rates even for government bonds, which may be considered to be risk-free. Banks cannot increase the

\footnotetext{
${ }^{1}$ Pension funds hold about $21 \%$ of total assets, whereas insurance sector and other remaining financial intermediaries hold $2 \%$ of the total assets each.

${ }^{2}$ For example, Montiel et al. (2012) indicate that Tanzania's stock market capitalization as a ratio of GDP is very low, at around 0.04 compared to 0.27 and 0.90 for low-income and advanced economies, respectively.
} 
deposits rate by as much since they have to build required reserves; banks suffer a deposits drain as investors reshuffle their portfolios towards higher interest bearing assets. As a result of the deposits drain, banks have to adjust their portfolios. If banks differentiate between making loans and holding government bonds, they will be unwilling to deplete their holdings of government bonds below a certain level. The bank will restrict the supply of loans instead, leading to a decline in investment spending, and a fall in economic activity.

Below is a schematic representation of BLC in which the vertical line " $\downarrow$ " indicates the direction of change. The horizontal line " $\rightarrow$ " indicates the channel through which the effect of a monetary policy change is transmitted to an economic activity. In this, a contractionary monetary policy (MP) - reflected by an increase in the policy rate-leads to a fall in bank reserves and bank deposits, subsequently leading to a decline in the bank loans to the private sector. In turn, it leads to contracting investment spending and then falling economic activity (output, $Y$ ).

$$
M P \uparrow \rightarrow \text { bank deposits } \downarrow \rightarrow \text { bank loans } \downarrow \rightarrow \text { Investment } \downarrow \rightarrow \downarrow Y
$$

Bernanke and Blinder (1988) indicate three conditions for the existence of BLC. First, firms should not be perfectly indifferent to different types of finance. They should be dependent on bank loans and cannot replace losses of bank loans emanating from the increase in the policy rate with other types of finance. If firms were indifferent between the two types of financing, then the decrease in supply of loans would not affect the firms at all. This condition is assumed to hold in Tanzania because banks are the major source of finance for economic activities. Second, the central bank should be able to affect supply of loans through changes it imposes on the volume of reserves. This is the focus of investigation by the current study. The assumption is that, for example, in a contractionary monetary policy, banks will not be able to offset the decrease in funds from deposits by raising funds from other sources. The third condition for a bank lending channel to hold, which we assume holds for the Tanzania is that, there are some imperfections in the adjustment of the aggregate price level. The imperfect price adjustment is necessary because monetary policy would have no impact if prices adjusted by the same percentage every time money supply was changed.

\subsection{Empirical Literature}

The literature is rich in studies which have tested the existence of BLC in different economies or in a group of countries. Most of these studies are based on developed economies. When estimating a bank loan supply function, the challenge is whether to use bank aggregate data or bank-level (panel) data. This is because the observed changes in the quantity of loans after a monetary policy movement may not entirely be attributed to a loan supply shifts. A monetary contraction could as well depress aggregate demand through the interest rate channel, thereby decreasing the demand for bank loans.

Studies that focus on bank aggregate data usually examine the response of aggregate loans, deposits and bond holdings to monetary policy shocks using the vector-autoregression (VAR) framework. This set up, however, does not allow the identification of supply and demand effects on credit growth. For example, Benanke and Blinder (1992) used innovations in 3-month Treasury bills rate (T-bill) to capture exogenous shifts in monetary policy. They found an inverse relationship between bank loans and tight monetary policy, and therefore supported the credit channel view in the US economy. As it will be shown later, by using bank-level data, mixed conclusions arise with respect to the strength of BLC in the US.

Due to difficulties in distinguishing shifts in loan demand from shifts in loan supply, studies focus on cross-section (bank-level) data and try to capture asymmetries in loan supply behaviour by examining reduced-form equations in bank loans to monetary policy measures. Implicit in this approach — which the current study adopts - is the assumption that, when asymmetries are present, loan supply shifts may be identified. Different studies have used disaggregated bank data in investigating the existence of BLC, particularly in developed economies. The studies include those on the US economy (such as Kashyap and Stein, 1995; Kashyap and Stein, 2000; Kishan and Opiela, 2000; and Ashcraft, 2006), in the UK (Huang, 2003; and Gambacorta, 2005), and in the Euro zone, (Altunvas et al., 2002; and Angeloni et al., 2003). Generally, most of these studies conclude that, a tight monetary policy leads to a decline in bank loans, which in turn has a negative impact on the economy. Also, empirical evidence supports the idea that well-capitalized and liquid banks are less affected by a monetary policy change than those with low capital and liquidity. Bank size seems to be irrelevant in some of the studies.

Specifically, Kashyap and Stein (1995) found that, growth in bank loans in the sub-segment of small commercial banks is most responsive to monetary policy. In another study, Kashyap and Stein (2000) divided banks in two categories: asset and liquidity size, and found that the smallest most illiquid banks were most responsive to monetary policy shocks. These findings were supported by Kishan and Opiela (2000) who divided banks with respect to size and capital strength. Ashcraft (2006), however, questions the existence of BLC in the US when using bank-level data. Ashcraft identified a differential response of loan supply to changes in the Federal Fund Rate across banks. When Ashcraft aggregated the bank data up to the state level, the loan market share of affiliated banks tended to mitigate the negative response of loan 
supply to changes in monetary policy. In addition, the aggregate elasticity of output to bank lending was very small. Cetorelli and Goldberg (2008) developed on the work of Kashyap et al. (1993), Kashyap and Stein (1995), and Kashyap and Stein (2000) for the US banking sector by bringing in an element of globalization. Cetorelli and Goldberg concluded that BLC existed in the US, and that, large globally-oriented banks extensively relied on internal capital markets to smoothen domestic liquidity shocks.

Likewise, Ehermann et al. (2001) used a panel of bank balance sheet data and tested for BLC in the Euro zone, and concluded that monetary policy did alter bank loan supply, and the effect was highly dependent on individual bank's liquidity level. Working on similar line, Westerlund (2003) used an ARDL panel data modelling approach and the results supported the existence of BLC in Sweden for the period 1998-2003.

Studies have also found evidence of BLC operation in Africa. Sichei (2005) investigated the existence of BLC in South Africa by using a specification as in Kashyap et al. (1993). Sichei regressed the total stock of gross loans on their lag, real GDP, and indicator of monetary policy, a vector of bank characteristics (size and capitalization) and the interaction of monetary policy and the bank characteristics. The findings supported that the joint effect of monetary policy and bank characteristics were statistically significantly and positive, implying banks with stronger balance sheets could cushion the effects of a tight monetary policy on their loan portfolio. Moreover, Sichei and Njenga (2010) investigated existence of BLC in Kenya by using data from banks annual audited balance sheets. They employed an IS/LM model with bank credit, in line with Bernanke and Blinder (1988). As a measure of capitalization, they used the ratio of excess capital to total risk-weighted assets; and for liquidity, they used the ratio of excess liquid assets to total liabilities. Sichei and Njenga found that, monetary policy had a more pronounced effect on banks with less liquid balance sheets and on those less capitalized.

By using a modelling approach as in Ehrmann et al. (2001), Chibundu (2009) examined existence of BLC in Nigeria by regressing total loans on its own lag, a measure of policy rate, GDP, inflation and bank characteristics, namely, size, liquidity and capitalization. The results were consistent with a weak BLC. The size and liquidity positions of banks were found to act as a source of information asymmetry that influenced banks' behaviour on loan supply following changes in monetary policy.

On Tanzania, Montiel et al. (2012) assessed the effect of monetary policy on aggregate demand by using VAR and aggregate data. Although the study is not comparable to the current study, Montiel et al. found no evidence of effective monetary transmission in Tanzania. Monetary policy transmission to loan rate was found to be weak. The authors concluded that, in order to complement the aggregate estimates, a more micro-based evidence of how individual banks basically respond to monetary policy shocks would be particularly important. The current study attempts to fill this gap.

\section{Methodology}

\subsection{Conceptual Framework}

BLC in Tanzania is analysed by using a profit-maximization framework developed by Stein (1998) and Ehrmann et al. (2001). By ignoring the time subscript $(t)$ in the specification, the balance sheet of bank $i$ is defined as:

$$
L_{i}+S_{i}=D_{i}+B_{i}+C_{i},
$$

where, $L$ is the volume of bank loans, $S$ is the securities, $D$ is the volume of the demand deposits from household, $B$ is the level of non-secured funding, and $C$ is the capital of the bank. The bank $i$ is assumed to act in a market characterized by monopolistic competition. The demand for bank loan $L_{i}^{d}$ can be written as:

$$
L_{i}^{d}=\phi_{1} y+\phi_{2} p+\phi_{3} r_{L}
$$

Loan demand is assumed to be positively related to economic activity $(y)$, and negatively with loan nominal interest rate $\left(r_{L}\right)$, so that: $\phi_{1}>0$ and $\phi_{3}<0$. In contrast, the coefficient of inflation $(p) \phi_{2}$ can be either positive or negative depending on the nature of the economy's steady-state equilibrium.

The bank capital is linked to the level of the loans, whereas the bank's holding of securities is linked to the level of the deposits as follows:

$$
\begin{aligned}
& C_{i}=k L_{i}, \text { and } \\
& S_{i}=c D_{i}
\end{aligned}
$$


The demand deposits $(D)$ are secured and they are demanded because of their role as a means of payment. Therefore, the demand deposits are negatively related to the interest rate of an alternative risk-free asset $\left(r_{s}\right)$ and this is taken as the monetary policy rate. This is written as:

$$
D=\beta_{0} r_{s} \text {, where } \beta_{0}<0
$$

Deposits are assumed to be exogenous to the bank, and they will drop after the monetary tightening (that is, after an increase in $r_{s}$ ). However, the bank has access to alternative sources of funds (e.g., interbank loan and debt securities), which are unsecured but attract interest. Since banks are perceived to be risky, the suppliers of unsecured finance ask for an external finance premium, the level of which depends on the bank's balance sheet health $\left(x_{i}\right)$ that is easily observed by all market participants. The higher is the $x_{i}$, the lower the external premium. So that, the interest rate of the unsecured financing $(B)$ is:

$$
r_{i}^{B}=r_{s}\left(\mu-c_{0} x_{i}\right), \text { where } \mu-c_{0} x_{i} \geq 1 \text { for } \forall
$$

Bank $i$ cannot raise unsecured funds if it is offered at less than $r_{i}^{B}$, and it can raise any amount of funds if it paid at least $r_{i}^{B}$. Since $r_{i}^{B}$ is a cost factor, the bank $i$ will not be ready to pay more than $r_{i}^{B}$. Assuming $B_{i}>0$, the profit of the bank $i \quad\left(\pi_{i}\right)$ can be written as:

$$
\pi_{i}=L_{i} r_{L, i}+S_{i} r_{s}-B_{i} r_{i}^{B}-\psi_{i},
$$

Where, $\psi_{i}$ captures bank-specific administrative costs and remuneration costs for the required capital holdings. By inserting (2) to (6) into (8), and assuming equilibrium in the loan market, yields:

$$
\pi_{i}=L_{i}\left(-\frac{1}{\phi_{3}} L_{i}+\frac{\phi_{1}}{\phi_{3}} y+\frac{\phi_{2}}{\phi_{3}} p\right)+s D_{i} r_{s}+\left[(1-k) L_{i}-(1-s) D_{i}\right] r_{i}^{B}-\psi_{i}
$$

By setting the first-order condition to zero, and inserting (7) in (9), the loan supply function can be written as:

$$
L_{i}=\frac{\phi_{1}}{2} y+\frac{\phi_{2}}{2} p-\frac{\phi_{3} \mu(1-k)}{2} r_{s}+\frac{\phi_{3} c_{0}(1-k)}{2} x_{i} r_{s}-\frac{\phi_{3}}{2} \frac{\partial \psi_{i}}{\partial L_{i}}
$$

Equation 10 is the standard loan equation in macro modelling. An implicit identifying assumption is that the interest rate loan demand elasticity does not depend on the bank characteristics $\left(x_{i}\right)$. In other words, the coefficient $\phi_{3}$ is the same for all banks. The assumption of homogenous reaction of the loan demand is crucial for the identification of monetary policy effects on loan supply because it rules out the case where, for example, small or large bank customers are more sensitive to interest rate changes. Such assumption seems quite reasonable for Tanzania in view of the fact that bank loans are the major source of external finance for firms.

Direct estimation of the bank loan supply function is favoured because if financial markets are characterized by asymmetric information, the effect of monetary policy through the interest rate channel could be amplified by changes in the availability of internal cash flow or of external finance (Brissimis and Delis, 2007). When banks are the main providers of funds for households or firms, monetary policy could affect the latter's spending via shifts in loan supply. Another reason relates to the fact that, estimation of reduced-form equations linking bank loans to monetary policy variables does not allow identification of the parameters of the structural model. Since due to data limitations, the observed asymmetries cannot be explicitly attributed to the output responses of firms that borrow from a particular size category of banks, and their implications for aggregate economic activity and transmission mechanism are not clearly visible (Kashyap and Stein, 2000).

A monetary policy tightening through an increase in the policy rate $\left(r_{s}\right)$ leads to a reduction in deposits in Equation 6 . However, banks can keep the asset side of their balance sheets unchanged only if they increase other sources of funding $B_{i}$ accordingly. But, the interest rate which banks have to pay for the funds was increased by the monetary policy tightening according to the Equation 7 . Banks pass at least part of this higher cost to their loan rate $\left(r_{L, i}\right)$, which in turn 
reduces the loan demand. Therefore, in Equation 10 it is expected that the monetary policy rate, $r_{s}$ has a negative effect to the supply of bank loans.

Equation 11 is a modified version of equation 10, and is used for empirical investigation:

$$
\begin{aligned}
& \Delta \ln L_{i t}=\lambda_{i}+\sum_{j=1}^{J} \alpha_{j} \Delta \ln L_{i t-j}+\sum_{j=0}^{J} \beta_{(+)} \Delta r p_{t-j}+\sum_{j=1}^{1} \delta_{j} x_{i t-1}+\sum_{j=1}^{1} \varphi_{(+)}\left(r_{t-1} * x_{i t-1}\right)+ \\
& \sum_{j=1}^{J} \theta_{j} \Delta \ln y_{t-j}+\sum_{j=1}^{J} v_{j} \Delta \ln p_{t-j}+\sum_{j=1}^{J} \underset{(-)}{\phi} \Delta \ln H H I_{t-j}+\sum_{j=1}^{J} \psi_{(-)} \Delta \ln N I I_{i t}-j+\underset{(-)}{\tau} N P L_{i t-1}+\underset{(-)}{\omega} L L P_{i t-1}+\varepsilon_{t}
\end{aligned}
$$

In Equation 11, $\Delta$ and $\ln$ indicate first difference and natural logarithm of the variables, respectively. The stochastic error term is expressed as $\varepsilon$. The variable $L$ is the real growth rate of bank loan for bank $i$ at time $t$. The variable $r_{p}$ denotes the appropriate interest rate measuring the monetary policy stance, here captured by the weighted average Treasury bill rate (mainly due to absence of active central bank policy rate). Higher values of $r_{p}$ correspond to a tighter monetary policy stance. The use of weighted average Treasury bill rate should be appropriate for Tanzania because the monetary authority targets monetary aggregates, and through open market operations, the resultant interest rate serves as an anchor of interest rates determination by banks. Commercial banks are expected to adjust their lending and deposits interest rates basing on the changes in the Treasury bill rates. ${ }^{3}$ It is assumed that, tighter monetary policy stance should result in slower credit growth. Because there will usually be a lag for monetary policy to take effect, and there may also be revesse gausality problem, lagged weighted average Treasury bill rate was used instead. The interaction variable $\left.r_{p t} x_{i t}\right)$ was included to measure the interaction of the monetary policy rate with the bank characteristics.

The parameters of interest in Equation 11 are the $\beta^{\prime} s$, and the $\varphi^{\prime} s$, which are assumed to be the same across banks. A monetary tightening is expected to reduce lending, hence $\sum_{j} \beta_{j}$ are expected to be negative. As for the interaction

terms, $\varphi^{\prime} s$ measure the effects of monetary policy which is expected to be weaker among larger, more liquid and

better capitalized banks. Large, more liquid and well capitalized banks are expected to be able to better shield their loans from monetary shocks by using their buffer of liquid assets and/or attracting funds from non-deposit sources, thus,

$\varphi^{\prime} s$ are assumed to be positive for asset size, liquidity and capitalization.

As mentioned earlier, bank characteristics may be a source of banks' asymmetric reaction to monetary policy changes. This view is in line with the literature in this area (see, for example, Kashyap and Stein, 1995 and 2000; and Peek and Rosengren, 1995). Therefore, captured in the model are vectors of bank-specific characteristics: asset size; liquidity; and capitalization, as specified by variable $x$ in equations 10 and 11. For the asset size, logarithm of total assets was used; while liquidity and bank capitalization were captured as the ratio of liquid assets (cash, interbank lending and securities) to total assets and the ratio of bank equity capital plus reserves to total assets, respectively. As shown below, bank characteristics variables are defined as deviations from the cross-sectional mean at each time period in the case of the size variable, so as to remove its trend, or the overall mean in the case of the bank strength variables (liquidity and capitalization) which do not have trend. All three criteria are normalized with respect to their average across all the banks in the sample in order to get indicators that sum to zero over the observations. This means that, for the regression model in equations 10 and 11, the average of the interaction terms $\left(r_{s} * x_{i}\right)$ is zero and the respective coefficient can be interpretable as the overall monetary policy effects on loans. For bank $i$ at time $t$, the size $(S)$, liquidity $(L Q)$ and capitalization $(C A)$ indicators are therefore computed as:

$$
S_{i t}=\log A_{i t}-\frac{1}{N} \sum_{i}^{N} \log A_{i t}
$$

\footnotetext{
${ }^{3}$ Interbank interest rate could be an alternative proxy for a policy rate, but since it was highly correlated with the Treasury bill rate during the study period, only the latter was thus used in the estimation.
} 


$$
\begin{aligned}
L Q_{i t} & =\frac{L A_{i}}{A_{i t}}-\frac{1}{T} \sum_{t=1}^{T}\left[\frac{1}{N} \sum_{i=1}^{N} \frac{L A_{i t}}{A_{i t}}\right], \\
C A_{i t} & =\frac{C_{i t}}{A_{i t}}-\frac{1}{T} \sum_{t=1}^{T}\left[\frac{1}{N} \sum_{i=1}^{N} \frac{C_{i t}}{A_{i t}}\right] .
\end{aligned}
$$

In order to isolate changes in total loans caused by movements in loan demand, a vector of control variables, $\mathrm{Z}$, was captured. In the literature, variables such as Gross Domestic Product (GDP), Consumer Price Index (CPI) and Real Exchange Rate (RER) have been used. Added to the model to control for demand effects is real GDP growth. This should be appropriate for Tanzania where an average of 7.1\% real GDP growth was observed for the period 2001-2012. Higher GDP growth is assumed to translate into higher credit growth. In line with Guo and Stepanyan (2011), GDP growth entered the model in its lags in order to avoid the problem of reverse causality, that is, high credit growth leads to higher GDP growth. Considerable stability was observed in exchange rate during the study period; therefore, inflation captures the effects of expected inflation on real credit growth. Tanzania experienced considerable inflationary pressure in the onset of the financial crisis emanating from the rise in food and energy prices in the world market, particularly from 2009. Ghosh and Gosh (1999) argue that the stock market index may also reflect the availability and attractiveness of alternatives to bank credit-equity finance in particular-from the demand side, but this is assumed away in this study because the stock market in Tanzania is still underdeveloped.

Innovation in this modelling is four-fold. Non-interest income for banks was added to the model to capture the effect of other services demanded by customers; banks ownership structure; the Herfindahl index ${ }^{\left(H H_{t}\right)}$ to take care of the degree of competition in the banking sector; and bank's risk position. The bank's risk position is captured by two risk measures: the ratio of nonperforming loans to total loans $\left(N P L_{t}\right)$ and the ratio of loan-loss provisions to nonperforming loans $\left(L L P_{t}\right)$. The former variable reflects past credit risk and may signal financial difficulties in the banking system, whereas the latter variable measures the severity of regulations on risk-taking in lending activities, respectively. If banks are reasonably well-behaved, they should tend to lower their credit supply in response to mounting credit risk and/or increasing loan-loss provisions being imposed upon them. ${ }^{4}$ Meanwhile, the Herfindahl index ${ }^{5}$ ranges from a low of 0 , indicating perfect competition, to a high of 10,000 , indicating complete monopoly. Greater values mean greater concentration and less competition, thus being negatively related to loan supply. Herfindahl index is computed from banks market shares of deposits. Also analysed is the distributional effect of monetary policy shocks along ownership structure of banks.

The existence of BLC is assessed through the signs and significance of the interaction coefficients ( $\varphi^{\prime} s$ coefficients) which measure the differential impact of monetary policy on bank lending depending on the bank's balance sheet strength, size and ownership structure. Also, according to the theory of the bank lending channel, the coefficient of the policy rate must be negative in order to imply that loans fall after a monetary policy tightening.

All bank-specific variables enter the equation with a lag. Equation 11 was estimated for banks real loans to the private sector-as a dependent variable - and this served as a benchmark equation. Separate estimations were made for the five largest banks (which are also most liquid and capitalized banks) and "other" (small) banks in the sample to capture asymmetric reactions to monetary policy. Also separate estimations were done for domestically- and foreign-owned banks, as well as privately- and public-owned banks.

The study used commercial banks' annual audited balance sheet data for the period 2001-2011. A total of 21 commercial banks (out of 48 banks) were used in estimations; these are the banks which were in operation throughout the study period. All data was obtained from BoT except the real GDP and CPI which were sourced from the Tanzania National Bureau of Statistics. The span of study period and data frequency was determined by data availability. The chosen period enabled the use of revised GDP, inflation and interest rates data. Also, the period was characterized by considerable financial development, and a relatively high reliance on market forces in determining interest rates. ${ }^{6}$

\footnotetext{
${ }^{4}$ Only loan-loss provision variable was used in this study due to unavailability of enough data on nonperforming loans.

${ }^{5}$ Herfindahl index measures concentration of the loans in the banking sector calculated as the sum of the squares of market shares for each firm. This is one method of summarizing the degree to which an industry is oligopolistic and the concentration of market control held by the largest firms in the industry.

${ }^{6}$ Montiel et al. (2012) suggest that investigation of the monetary transmission in Tanzania should be based on post-2000 data following a delayed financial development to financial reforms started in the 1990s.
} 


\subsection{Descriptive Statistics of the Variables}

The appended tables I-A and I-B summarize descriptive statistics of the variables in a sample of 21 banks, whereas the correlation coefficients of the same are detailed in appendix Table I-C. Appendix Table I-A shows that the mean and standard deviations of the logarithm of real credit to the private sector are 6.25 and 1.66, respectively. The Jarque-Bera test statistic suggests non-normality in the data. Meanwhile, the share of the top five banks assets to total assets declined from $83.1 \%$ in $2001-2003$ to $58.8 \%$ in $2008-2011$ in favour of the medium size banks (appendix Table I-B). This is an indication of increased competition in the sector. The medium size banks and the bottom five banks were more capitalized than the top five5 banks, probably indicating difficulties to smaller banks in accessing other sources of funds. In line with this, smaller banks also hold sizeable amount of their total assets in liquid assets. Meanwhile, foreign-owned banks, which accounted for about 54.8\% of the total assets in the period 2001-2011, were relatively more capitalized, with the ratio of their capital to total assets standing at $4.4 \%$ compared to $3.0 \%$ of domestically-owned banks, suggesting that foreign-owned banks could be in a better position to cushion negative effects on their balance sheets. For domestically-owned banks, they hold a significant share of their assets in liquid assets for that effect. During the period 2001-2011, domestically-owned banks held an average of $21.9 \%$ of their assets in liquid assets compared to $14.6 \%$ held by foreign-owned banks.

Meanwhile, the growth in real bank credit to the private sector is positively related to real GDP growth, competition and capitalization measures, and negatively correlated with the T-bill rate (policy rate), perceived risk, and liquidity and size measures (appendix Table I-C). High correlation between the exogenous variables cannot be denied either, particularly between real GDP and inflation; real GDP and competition measure; competition measure and inflation; and bank size measure and non-interest income. Appended figures I-A to I-D depict the trends of the series in which banks are numbered from 1 to 21 . It is evident from the plots that real credit to the private sector by most of the banks increased during the study period. This is consistent with the increase in the size of banks and increasing competition in the banking sector. The central bank seems to have followed a restrictive monetary policy stance-reflected by the rise in Treasury bill rate - during the periods 2001-2006 and 2010-2011. Generally, the series seem to be non-stationary, save for banks' balance sheet strength indicators (i.e., liquidity and capitalization). Stationarity of the series was further tested by using Im, Pesaran and Shin W-stat and Augmented Dickey-Fuller methods for the panel and time series data, respectively. The results are summarized in Table 1. The unit root results suggest that the null hypothesis of non-stationarity of the series in levels cannot be rejected for most of the series. ${ }^{7}$ When differenced once, all the series are accepted to be stationary with very high probability.

Table 1. Unit root tests for the variables

\begin{tabular}{|c|c|c|c|c|c|}
\hline \multirow[b]{2}{*}{ Variable } & \multicolumn{2}{|c|}{ Leve1 } & \multicolumn{2}{|c|}{ 1st difference } & \multirow{2}{*}{$\begin{array}{c}\text { Lags for } \\
\text { each } \\
\text { estimatio } \\
\mathrm{n} \\
\end{array}$} \\
\hline & $\begin{array}{c}\text { Individual } \\
\text { intercept }\end{array}$ & $\begin{array}{l}\text { Individual } \\
\text { trend and } \\
\text { intercept }\end{array}$ & $\begin{array}{l}\text { Individua } \\
1 \\
\text { intercept }\end{array}$ & $\begin{array}{c}\text { Individual } \\
\text { trend and } \\
\text { intercept }\end{array}$ & \\
\hline Log real credit to private sector* & $-1.30^{+}$ & 0.67 & $-2.31^{+++}$ & $-1.56^{+++}$ & 1 \\
\hline Log real GDP** & -1.61 & -0.88 & $-2.94^{+}$ & $-5.19^{++}$ & 1 \\
\hline $\log$ CPI** & 4.14 & -0.32 & -0.64 & -2.89 & 1 \\
\hline Log non-interest income** & 2.98 & -0.68 & $-4.33^{+++}$ & $-2.25^{++}$ & 1 \\
\hline Loan-1oss provision** & $-1.84++$ & 1.04 & $-2.39^{+++}$ & -0.67 & 1 \\
\hline Herfndah1 index* & -1.11 & $-3.46^{+}$ & $-3.50^{++}$ & -2.85 & 1 \\
\hline T-bill rate** & -1.55 & -2.45 & -1.32 & -0.70 & 1 \\
\hline Size* & 1.39 & -0.83 & $-4.47^{+++}$ & -0.37 & 1 \\
\hline Liquidity* & -1.13 & $-1.73^{++}$ & $-5.97^{+++}$ & $-1.81^{++}$ & 1 \\
\hline Capitalization* & $-3.39^{+++}$ & $-1.53+$ & $-4.55^{+++}$ & $-1.32^{+}$ & 1 \\
\hline
\end{tabular}

Note: * and ** imply tests using Im, Pesaran and Shin W-stat and Augmented Dickey-Fuller Tests, respectively. ${ }^{+(++)+++}$imply statistically significant at $10 \%(5 \%) 1 \%$ levels.

Source: Author's computations.

On account of the descriptive statistics, and given a narrow panel of only 21 banks, it was reasonable to proceed using

\footnotetext{
${ }^{7}$ Unit root results for the time series should be interpreted with caution because of the shortness of the sample period (11 years).
} 
first difference dynamic GMM as per Arellano and Bond (1991). However, in order to control for weaknesses associated with the use of fixed effect and first difference GMM estimators, a system GMM approach, which combines both regression in differences and in levels as suggested by Blundell and Bond $(1998)^{8}$, was employed. A dynamic panel data analysis is justified on two reasons. First, there is a close banker-customer relationship that develops and may create lock-in effects, thus making it costly for the borrower to change bank (Morgan, 1998). Thus, lagged values of loans affect current loan positions. In other words, under these circumstances, the bank acquires "informational monopoly over a client" and hence it is extremely costly for a customer to change a bank, because the services of the new bank will be more expensive, since it needs to collect information about the new customer. Second, monetary policy only impacts lending behaviour with a lag due to long-term contractual commitments, hence lagged values of the explanatory variables also affect current loan positions (Sichei, 2005). Third, the presence of significant autocorrelation in panel regression suggests that a dynamic panel is more appropriate. With this, testing for I(1) could be seen as complementary to the decision because it is unlikely to get spurious regression in panels because, as the number of $\mathrm{N}$ goes to infinity, it would dominate the time $\mathrm{T}$ going to infinity.

The use of this approach notwithstanding, the results obtained after controlling for fixed and random effects, as well as dynamic panel data effects as suggested by Arellano-Bond are also reported for robustness check purposes.

\section{Regression Results and Discussion}

The empirical results are summarized in tables 2-5. The general model results are reported in Table 2. The results are obtained from system dynamic panel data estimations, where the real credit to the private sector was used as a dependent variable. The independent variables are the real GDP, CPI, bank characteristics, weighted average Treasury bill rate, and interaction terms between the policy rate and bank characteristics. Banks non-interest income, a measure of competition in the banking sector and banks' risk perception were dropped from the model because their coefficients were found to be statistically insignificant. ${ }^{9}$ In all estimations robust standard errors were used. The null hypothesis that coefficients of the independent variables are jointly non-zero was rejected with very high probability, and that of no autocorrelation in the first differenced errors could not be rejected in most of estimations, indicating well-specified models.

Here, discussion is made to the findings basing on the models in which the interaction terms have two lags. This should be appropriate for Tanzania, where there are considerable long-term contractual arrangements between lenders and borrowers so much as to attract 'prime' rates on loans.

\subsection{The Existence of BLC in Tanzania}

As depicted in Table 2, the coefficient of the policy rate is negative and statistically significant at the conventional $1 \%$ and 5\% levels, implying that bank loans fall after a monetary policy tightening. In model 3, an increase in the policy rate by one percentage point would reduce the ratio of bank credit to GDP, which was $20 \%$ in 2012, by 0.57 percentage points in the short run and 1.39 percentage points in the long run. ${ }^{10}$ Furthermore, all coefficients of the interaction terms are positive (as expected), and those of bank size and capitalization are statistically significant at $1 \%$ level.

\footnotetext{
${ }^{8}$ Inclusion of lagged dependent variables as regressors renders OLS estimator in a fixed effect model biased and inconsistent resulting in inefficient estimates. Likewise, if the lagged dependent and explanatory variables are persistent over time or nearly a random work, then lagged levels of these variables are weak instruments for the regression equation in differences.

${ }^{9}$ Results of the model with all variables are appended as Table II-A.
}

${ }^{10}$ Long-run coefficients were computed as: $\frac{\beta}{(1-\alpha)}$, where $\beta$ and $\alpha$ are the coefficients of the policy rate and the lag of real credit, respectively. 
Table 2. The effect of monetary policy on bank loan supply to the private sector

\begin{tabular}{|c|c|c|c|c|c|c|}
\hline \multicolumn{7}{|c|}{ Dependant variable: Real bank credit to the private sector } \\
\hline \multirow[b]{2}{*}{ Variable } & \multicolumn{2}{|c|}{ Model 1: No Lag } & \multicolumn{2}{|c|}{ Model 2: 1 Lag } & \multicolumn{2}{|c|}{ Model 3: Lag† } \\
\hline & Coefficient & P-value & Coefficient & P-value & Coefficient & P-value \\
\hline Inrlp(-1) & 0.094 & 0.389 & 0.212 & 0.301 & $0.594 * * *$ & 0.000 \\
\hline Inrgdp & $5.979 * * *$ & 0.000 & $4.931 * * *$ & 0.000 & $4.715^{* *}$ & 0.010 \\
\hline Incpi & $-3.870 * * *$ & 0.000 & $-3.406 * * *$ & 0.000 & $-3.947 * *$ & 0.013 \\
\hline itbl & $-0.025 * *$ & 0.048 & $-0.041 * * *$ & 0.007 & $-0.0283^{* *}$ & 0.013 \\
\hline S & $0.608 * * *$ & 0.000 & 0.198 & 0.136 & $0.286 * * *$ & 0.009 \\
\hline LQ & -0.569 & 0.510 & -0.903 & 0.240 & 0.114 & 0.773 \\
\hline CA & $-1.529 * *$ & 0.058 & -0.467 & 0.652 & $-0.688 * *$ & 0.035 \\
\hline$S^{*}$ itbl & $0.011 * *$ & 0.055 & $0.025 * * *$ & 0.007 & $0.012^{* * *}$ & 0.000 \\
\hline LQ*itbl & -0.056 & 0.170 & 0.016 & 0.751 & $0.027^{*}$ & 0.720 \\
\hline$C A^{*}$ itbl & 0.058 & 0.339 & 0.059 & 0.413 & $0.157^{* * *}$ & 0.000 \\
\hline Constant & $-76.195 * * *$ & 0.000 & $-61.013^{* * *}$ & 0.000 & $-57.55 * *$ & 0.011 \\
\hline \multicolumn{7}{|c|}{$\begin{array}{l}\text { Note: Inrlp is log real bank credit to the private sector, Inrgdp, log real GDP; Icpi, log consumer price index; } S, L Q \text {, } \\
\text { and } C A \text { are bank size, liquidity and capitalization levels respectively; and * is a multiplication sign. } \\
+2 \text { Lags on the interaction terms; System dynamic panel-data estimation; Sample: } 2001-11\end{array}$} \\
\hline Number of obs & 210 & & 210 & & 189 & \\
\hline Lags on Instruments & 4 & & 4 & & 4 & \\
\hline Wald chi ${ }^{2}$ & $971.64 * * *$ & & $370.90 * * *$ & & $2321.30 * * *$ & \\
\hline \multicolumn{7}{|c|}{$\begin{array}{l}\text { HO: No autocorrelation in first- } \\
\text { differenced errors (AR(1))--p value }\end{array}$} \\
\hline for lag 1 & 0.196 & & 0.258 & & 0.002 & \\
\hline \multicolumn{7}{|c|}{$\begin{array}{l}\text { HO: No autocorrelation in first- } \\
\text { differenced errors (AR(1))--p value }\end{array}$} \\
\hline for lag 2 & 0.381 & & 0.223 & & 0.077 & \\
\hline
\end{tabular}

Source: Author's computations.

In order to test the robustness of the results, estimations were also made controlling for fixed and random effects, as well as dynamic panel data effects as suggested by Arellano-Bond. The findings are appended as Table II-B, and they support the null hypothesis of existence of BLC in Tanzania. In particular, the coefficient of the policy rate is negative and statistically significant. Its magnitude, at 0.026 , compares well with 0.0283 obtained in the parsimonious system dynamic panel data model. Likewise, coefficients of the interaction terms on bank capitalization and size are positive and statistically significant, supporting that the two bank characteristics could be important sources of information asymmetry in the banking system.

\subsection{Role of Bank size in Explaining BLC}

To avoid over-parameterization, the data set was split into two: small banks and large banks, and the results are summarized in Table 3. The coefficient of the policy rate is negative, as expected, and statistically significant in the equations for the small banks, but statistically insignificant in the models for large banks. Moreover, as before, the coefficients of the interaction terms of the policy rate and size and capitalization measures are statistically significant at $5 \%$ and $1 \%$, respectively (model 2). Since the coefficient of the policy rate for the small banks (model 2) is -0.037 compared to -0.008 for large banks (model 2), it is likely that small banks are more responsive to a monetary policy shock than large banks. In the short to long term, for example, reaction by small banks to a percentage point increase in the policy rate would lead to a fall in the share of credit to GDP by 0.74-1.91 percentage points. 
Table 3. Distributional effect of monetary policy on small- and large-bank loan supply

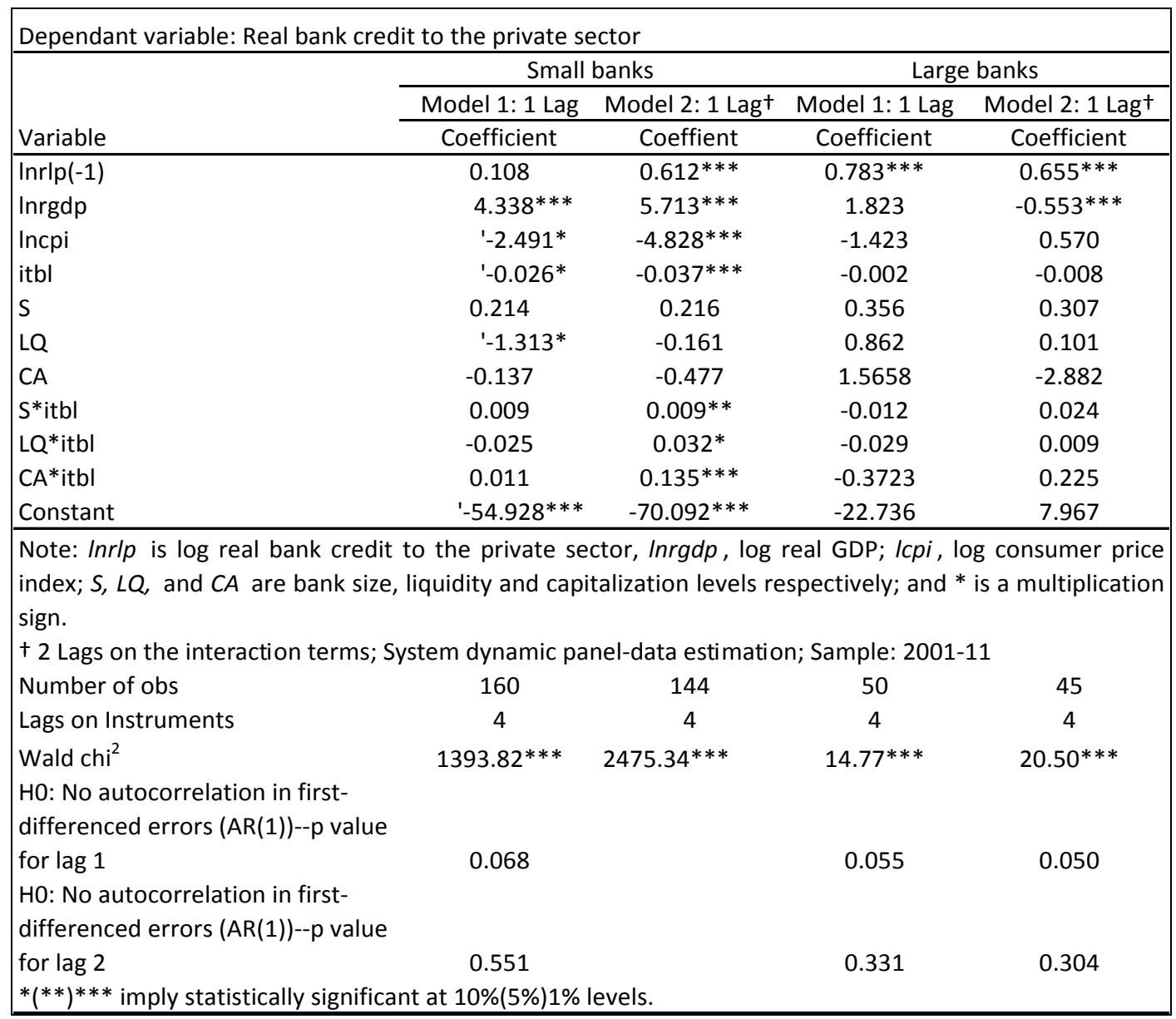

Source: Author's computations.

\subsection{Role of Ownership Structure in Explaining BLC}

In order to capture asymmetric reaction of banks basing on the ownership structure, separate estimations were made for domestically-owned banks against foreign-owned banks, as well as privately-owned banks against public-owned banks. The results are summarized in tables 4 and 5 .

\section{Domestically-owned banks against foreign-owned banks}

Results in Table 4 support the argument that, BLC in Tanzania may be operating through both domestically- and foreign-owned banks (model 2 for domestically- and foreign-owned banks). The effect of a policy change is, however, stronger through domestically-owned banks compared to foreign-owned banks, with a long-run reduction of the ratio of credit to GDP of 1.5 percentage points and 1.4 percentage points, respectively. This notwithstanding, the source of asymmetric reaction differs across the banks, in which bank size plays an important role for domestically-owned banks, while both capitalization and size matter for foreign-owned banks. With an interaction term coefficient of 0.126 , more capitalized foreign banks seem to be much less responsive to a policy change than do large or more capitalized domestically-owned banks. This may be due to the fact that foreign-owned banks have the ability to access other sources of funds abroad such as equity, which enable them to meet their loan commitments even in an environment of policy rate increases. 
Table 4. Effect of monetary policy on domestically- and foreign-owned bank loan supply

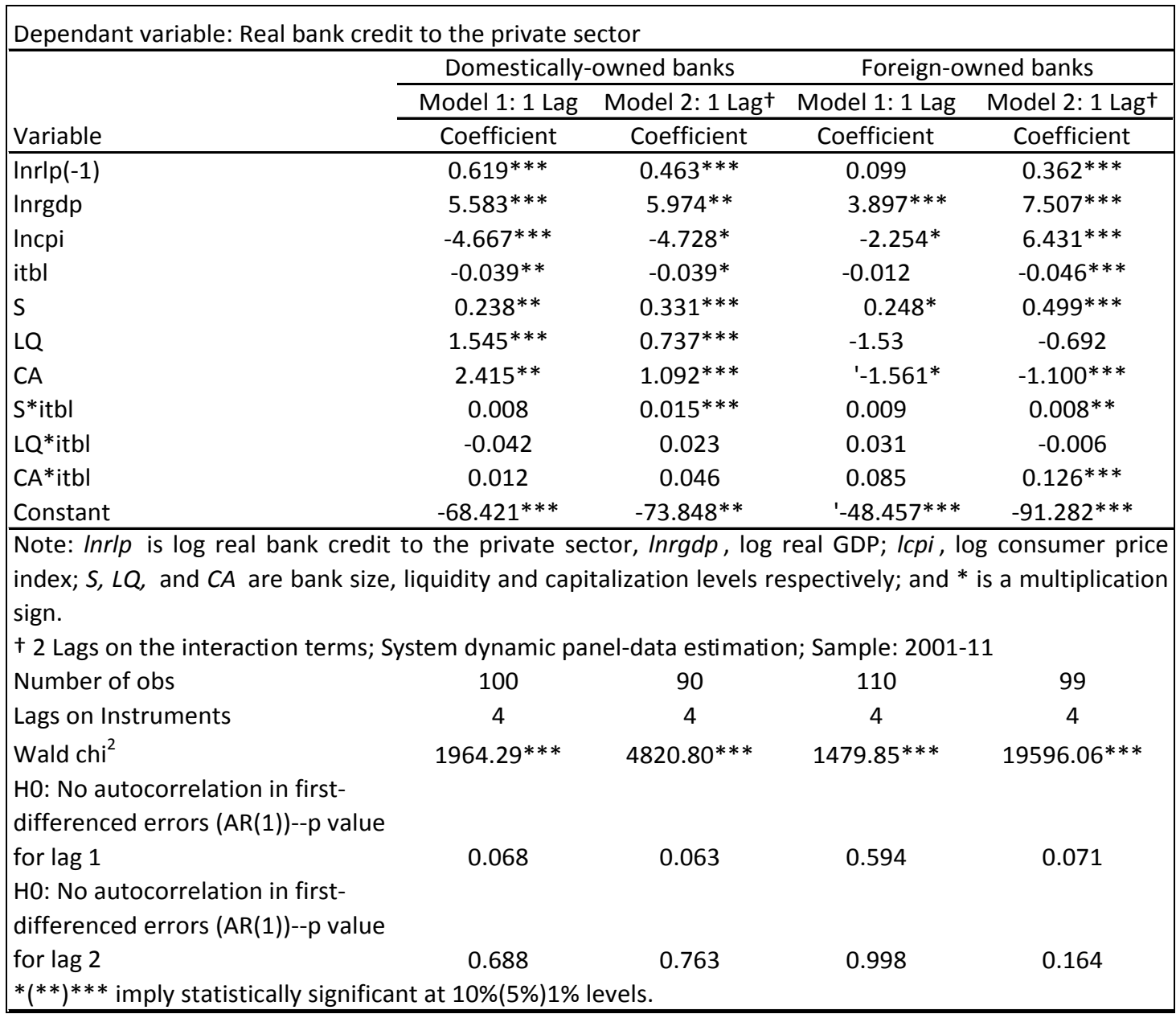

Source: Author's computations.

\section{Privately-owned banks against public-owned banks}

The presence of both privately- and public-owned banks may as well be a source of asymmetric reaction in the banking system. This is because, unlike privately-owned banks, public-owned banks are not under pressure to make profit and, therefore, may opt not to cut-down their loans following a monetary policy shock. In Table 5, the coefficient of policy rate for privately-owned banks (model 2) is statistically significant, whereas that for public-owned banks (model 2) is insignificant. This supports the presence of a weak BLC through public-owned banks. Conversely, for privately-owned banks, the effect of one percentage point increase in the policy rate would lead to a reduction of the ratio of credit to GDP by $0.8-1.7$ percentage points in the short to long term. 
Table 5. Effect of monetary policy on privately- and public-owned banks' loan supply

Dependant variable: Real bank credit to the private sector

\begin{tabular}{|c|c|c|c|c|}
\hline \multirow[b]{3}{*}{ Variable } & \multicolumn{2}{|c|}{ Privately-owned banks } & \multicolumn{2}{|c|}{ Public-owned banks } \\
\hline & Model 1: 1 Lag & Model 2: 1 Lag $^{\dagger}$ & Model 1: 1 Lag & Model 2: 1 Lag† \\
\hline & 1 Lag & 1 Lag $^{\dagger}$ & $1 \mathrm{Lag}$ & $1 \mathrm{Lag}^{\dagger}$ \\
\hline $\ln r \operatorname{lp}(-1)$ & $0.763^{* * *}$ & $0.563^{* * *}$ & $0.649 * *$ & $0.413^{* * *}$ \\
\hline Inrgdp & $3.552 * * *$ & $5.222 * * *$ & 0.164 & $0.714^{* * *}$ \\
\hline Incpi & $-3.203 * * *$ & $-4.653 * * *$ & -1.423 & $0.744^{* * *}$ \\
\hline itbl & -0.001 & $-0.038 * * *$ & -0.099 & -0.016 \\
\hline S & -0.072 & 0.299* & -0.346 & $0.254 * * *$ \\
\hline LQ & $-2.302 * *$ & -0.469 & 1.605 & $0.293^{*}$ \\
\hline $\mathrm{CA}$ & $-0.835^{*}$ & $-0.707^{*}$ & $16.099 * * *$ & -0.546 \\
\hline$S^{*}$ itbl & 0.005 & $0.010 * * *$ & 0.056 & $0.028 * * *$ \\
\hline LQ*itbl & $0.186 * * *$ & 0.017 & -0.141 & 0.028 \\
\hline$C A^{*}$ itbl & $0.161^{* * *}$ & $0.145^{* * *}$ & -0.536 & 0.051 \\
\hline Constant & $-42.599 * * *$ & $-62.562 * * *$ & 7.504 & $-11.600 * * *$ \\
\hline \multicolumn{5}{|c|}{$\begin{array}{l}\text { Note: Inrlp is log real bank credit to the private sector, Inrgdp, log real GDP; Icpi, log consumer price } \\
\text { index; } S, L Q \text {, and } C A \text { are bank size, liquidity and capitalization levels respectively; and * is a multiplication } \\
\text { sign. } \\
+2 \text { Lags on the interaction terms; System dynamic panel-data estimation; Sample: } 2001-11\end{array}$} \\
\hline Number of obs & 160 & 144 & 50 & 45.000 \\
\hline Lags on Instruments & 4 & 4 & 4 & 4.000 \\
\hline Wald chi ${ }^{2}$ & $791.16 * * *$ & $1382.66 * * *$ & $34.09 * * *$ & $82.37 * * *$ \\
\hline \multicolumn{5}{|c|}{$\begin{array}{l}\text { HO: No autocorrelation in first- } \\
\text { differenced errors }(A R(1))--p \text { value }\end{array}$} \\
\hline for lag 1 & 0.083 & 0.018 & 0.502 & 0.148 \\
\hline \multicolumn{5}{|c|}{$\begin{array}{l}\text { HO: No autocorrelation in first- } \\
\text { differenced errors }(A R(1))--p \text { value }\end{array}$} \\
\hline for lag 2 & 0.790 & 0.159 & 0.647 & 0.274 \\
\hline
\end{tabular}

Source: Author's computations.

\subsection{Economic Importance of BLC}

The discussion in the subsections above has concentrated on the statistical significance of the model estimates. In this sub-section, we assess whether BLC has any economic significance in Tanzania. The focus is put on the coefficient of the interaction term between the policy rate and the bank capitalization measure (Table 2, model 2). ${ }^{11}$ The estimate of the coefficient of the interaction term is 0.157 . Further, in 2011, the ratio of capital (equity plus reserves) to total assets for the five largest banks was 0.0517 , while that for the small banks ('other' 16 banks) was 0.0338 . Multiplying the coefficient of the interaction term (i.e., 0.157) by the difference between the ratios of capital to total assets (which is 0.018 ) gives a difference in the change in log lending of approximately 0.003 . This implies that, in response to a 100 basis points (bps) change in the policy rate, more capitalized bank would record an annual growth in lending of approximately $30 \mathrm{bps}$ more than the poorly capitalized bank. This level is non-trivial for a developing financial sector such as that of Tanzania. ${ }^{12}$

\section{Conclusion and Policy Implications}

Monetary policy can influence economic activity in the short to medium term, through a number of channels, including interest rate, bank lending, balance sheet, and exchange rate channels. An important requirement in the design of appropriate monetary policy is, therefore, to understand the major transmission channels for the specific economy. This study uses a dynamic panel data models to empirically investigate whether changes in the monetary policy in Tanzania

\footnotetext{
${ }^{11}$ Capitalization is chosen because it appears to be useful, not only in the general equation, but also in the equations for small banks and privately-owned banks, relatively more affected by monetary policy changes.

${ }^{12}$ Kashyap and Stein (2000) found an annual lending growth of 60 bps between categories of large and small banks in the US.
} 
influence bank lending behaviour. It also evaluates the distributional effects of the monetary policy on banks with different balance sheet characteristics and ownership structures.

The findings suggest that, the coefficient of the policy rate is negative and statistically significant, as expected. Likewise, all coefficients of the interaction terms between the policy rate and bank size and capitalization measures are positive and statistically significant at $1 \%$ level. In separating the data set, in line with ownership structures, bank size, and capitalization, the respective coefficients were also statistically significant. Furthermore, the lending channel seems to be stronger through domestically- and privately-owned banks than it is with foreign- and public-owned banks.

The findings lend support to the hypotheses that: first, BLC operates in Tanzania, suggesting that bank loans are important channel through which monetary policy shocks are transmitted to the economy. The findings mirror the arguments that the banking sector still dominates the financial system in the country, whereas money, capital, and real estate markets are still at their infant stages. Banks account for about three-quarters of the financial sector's assets, reflecting banks dominance of sources of funding. Also, about two-thirds of bank funding comes from private sector deposits, probably constraining banks in offsetting the decrease in funds from deposits by raising funds from other sources. Second, banks react asymmetrically to policy changes influenced by size, capital strength and ownership structure. The lending channel is stronger through domestically-owned banks and privately-owned banks than it is with foreign-owned banks and public-owned banks. The reason is that, for foreign-owned banks, they could enhance their capital through raising of equity abroad and/or benefit from retained earnings (reserves), while for public-owned banks, it could be because they are not under pressure to make profit and, therefore, may opt not to cut-down their loans following a monetary policy shock. The findings on asymmetric reaction to monetary policy due to ownership structure, together with the quantification of the economic importance of BLC borrowing from Tanzanian data constitute the main contribution of this study since they were not covered in the previous studies on Africa (see, for example, Sichei, 2005; Chibundu, 2009; and Sichei and Njenga, 2010).

Although bank liquidity appears to be statistically insignificant in most of the estimations, this does not completely rule out its role in influencing banks' lending behaviour in the country. As shown earlier, the ratio of banks liquid assets to total assets was on average $25.63 \%$ between 2001 and 2012, and the policy rate is negatively correlated with the liquidity indicator. To the extent that the banking sector holds significant liquidity, more liquid banks may be in a better position to offset an exogenous contraction in deposits without cutting their loan's portfolio, thus isolating loan growth from monetary policy changes. The anomaly with the liquidity measure could partly be attributed to the modelling approach. Further tests could, therefore, be done allowing for monopolistic tendencies and excess liquid condition in the model. Future studies could also attempt to shade light on how monetary policy changes affect the economic activity through BLC. These weaknesses notwithstanding, the findings in this study provide useful insights on the bank lending channel of monetary policy transmission in Tanzania.

The policy implications are that, in assessing the stance of the monetary policy, beside short-term interest rates, it is critical for the monetary authority to trace banks reaction to monetary policy changes as reflected in loan supply to the private sector. Such analysis should also factor in possible asymmetric responses by banks influenced by size, capitalization, as well as ownership structure.

\section{Acknowledgement}

I would like to thank the African Economic Research Consortium for their financial support and, for providing forums to present drafts of this paper. I am very grateful to Prof. Christopher Adam, Prof. Bo Sjö and Prof. Victor Murinde for their very constructive comments. Also, my gratitude goes to the management of the Bank of Tanzania for allowing me to carry out the study. However, any omissions or remaining errors in this paper should entirely be ascribed to the author alone.

\section{References}

Altunvas, Y., Fazyloz, O., \& Molyneux, P. (2002). Evidence on the bank lending channel in Europe. Journal of Banking and Finance, 26, 2093-2110. https://doi.org/10.1016/S0378-4266(02)00201-7

Angeloni, I., Kashyap, A., \& Mojon, B. (eds). (2003). Monetary Policy Transmission in the Euro Area. Cambridge, United Kingdom: Cambridge University Press. https://doi.org/10.1017/CBO9780511492372

Arellano, M., \& Bond, S. (1991). Some tests of specification for panel data: Monte Carlo evidence and application to employment equations. Review of Economic Studies, 78, 277-297. https://doi.org/10.2307/2297968

Ashcraft, A. (2006). New evidence on the lending channel. Journal of Money, Credit, and Banking, 38, 751-775. https://doi.org/10.1353/mcb.2006.0037

Bank of Tanzania (BoT). (2001a). Tanzania Mainland's 50 Years of Independence: A Review of the Role and Functions of the Bank of Tanzania (1961-2011). Bank of Tanzania, Dar es Salaam. 
Bank of Tanzania (BoT). (2001b). Banking Supervision Annual Report for 2011, 15 $5^{\text {th }}$ Edition. Bank of Tanzania, Dar es Salaam.

Bank of Tanzania (BoT). (2010). Banking Supervision Annual Report for 2010, $14^{\text {th }}$ Edition. Bank of Tanzania, Dar es Salaam.

Bernanke, B., \& Blinder, A. (1988). Money, credit and aggregate demand. American Economic Association, Paper and Proceedings, 78(2), 901-921. https://doi.org/10.3386/w2534

Bernanke, B., \& Blinder, A. (1992). The federal funds rate and the channel of monetary transmission”. The American Economic Review, 82, 901-921.

Blundell, R., \& Bond, S. (1998). Initial conditions and moment restrictions in dynamic panel data models. Journal of Econometrics, 87, 115-143. https://doi.org/10.1016/S0304-4076(98)00009-8

Brissimis, S. N., \& Delis, M. D. (2007). Identification of a loan supply function: A cross-country test for the existence of a bank lending channel. Working Paper No. 54. Bank of Greece, January.

Cetorelli, N., \& Goldberg, L. S. (2008). Banking globalization, monetary transmission, and the lending channel. NBER Working Paper No. 14101. https://doi.org/10.3386/w14101

Chibundu, E. C. (2009). Bank specific characteristics and monetary policy transmission in Nigeria: Evidence of bank lending channel in an emerging market economy. Paper Presented at the $65^{\text {th }}$ Annual Congress of the Institute of International Public Finance (IIPF), Cape Town, South Africa, 13-16 August.

Demirguc-Kunt, A., \& Maksimovic, V. (1998). Law, finance, and firm growth. Journal of Finance, 53, 2107-2137. https://doi.org/10.1111/0022-1082.00084

Erhmann, M., Gambarcota, L., Martines-Pages, J., Sevestre, P., \& Worms, A. (2001). Financial systems and the role of banks in monetary transmission in the Euro area. ECB Working Paper No. 105.

Gambacorta, L. (2005). Inside the bank lending channel. European Economic Review, 49, 1737-1759. https://doi.org/10.1016/j.euroecorev.2004.05.004

Ghosh, S. R., \& Gosh, A. (1999). East Asia in the aftermath: Was there a crunch? IMF Working Paper No. 99/38.

Guo, K., \& Stepanyan, V. (2011). Determinants of bank credit in emerging market economies. IMF Working Paper No. $11 / 51$.

Huang, Z. (2003). Evidence of a bank lending channel in the UK. Journal of Banking and Finance, 27, 491-510. https://doi.org/10.1016/S0378-4266(02)00388-6

Kashyap, A. K., \& Stein, J. C. (1995). The impact of monetary policy on bank balance sheets. Carnegie-Rochester Conference Series on Public Policy, 42, 151-195. https://doi.org/10.1016/0167-2231(95)00032-U

Kashyap, A. K., \& Stein, J. C. (2000). What do a million observations on banks say about the transmission of monetary policy? American Economic Review, 90, 407-428. https://doi.org/10.1257/aer.90.3.407

Kashyap, A. K., Stein, J. C., \& Wilcox, D. W. (1993). Monetary policy and credit conditions: Evidence from the composition of external finance. American Economic Review, 83(1), 78-98.

King, R. G., \& Levine, R. (1993a). Finance and growth: Schumpeter might be right. Quarterly Journal of Economics, 108, 717-738. https://doi.org/10.2307/2118406

King, R. G., \& Levine, R. (1993b). Finance, entrepreneurship, and growth: Theory and evidence. Journal of Monetary Economics, 32, 513-542. https://doi.org/10.1016/0304-3932(93)90028-E

Kishan, R., \& Opiela, T. (2000). Bank size, bank capital and the bank lending channel. Journal of Money, Credit and Banking, 32, 121-141. https://doi.org/10.2307/2601095

Levine, R., \& Zervos, S. (1998). Stock markets, banks, and economic growth. American Economic Review, 88, 537-558.

Mbowe, W. E. N. (2010). Financial Sector Reforms and Development and their Macroeconomic Implications in Tanzania. The Print Factory, Dar es Salaam.

Mishkin, S. F. (1995). Symposium on the monetary transmission mechanism. Journal of Economic perspectives, 9(4), 3-10. https://doi.org/10.1257/jep.9.4.3

Mishra, P., Montiel, P., \& Spilimbergo, A. (2010). Monetary transmission in low income countries. IMF Working Paper No. 10/223.

Montiel, P., Adam, C., Mbowe, W., \& O'Connell, S.. (2012). Financial architecture and the monetary transmission mechanism in Tanzania. International Growth Centre, Working Paper No. 12/0343. 
Morgan, P. D. (1998). The credit effects of monetary policy: Evidence using loan commitments. Journal of Money Credit and Banking, 30, 102-118. https://doi.org/10.2307/2601270

Nord R., Sobolev, Y., Dunn, D. , Hajdenberg, A., Hobdari, N., Maziad, S., \& Rondet, S. (2009). Tanzania: The Story of an African Transition. Washington, D.C.: IMF.

Peek, J., \& Rosengren, E. S. (1995). Is bank lending important for the transmission of monetary policy? An overview. New England Economic Review, Federal Reserve Bank of Boston, Issue November, 3-11.

Ramlogan, C. (2004). The transmission mechanism of monetary policy: Evidence from the Caribbean". Journal of Economic Studies, 31(5/6), 435-447. https://doi.org/10.1108/01443580410555537

Sichei, M. M. (2005). Bank lending channel in South Africa: Bank level dynamic panel data analysis. Department of Economics, University of Pretoria, South Africa.

Sichei, M. M., \& Njenga, G. (2010). Does bank-lending channel exist in Kenya? Bank-Level Panel Data. Mimeo. Central Bank of Kenya, Nairobi.

Stein, J. (1998). An adverse selection model of bank asset and liability management with implications for the transmission of monetary policy, RAND Journal of Economics, 29(3), 466-486. https://doi.org/10.2307/2556100

Westerlund, J. (2003). A panel data test of the bank lending channel in Sweden. Department of Economics, Lund University, December 2003.

World Bank. (2011). World Development Indicators 2011. The World Bank, USA.

\section{Appendix I: Descriptive statistics}

Table I-A. Descriptive statistics of the variables

\begin{tabular}{|c|c|c|c|c|c|c|c|c|c|c|}
\hline & $\begin{array}{l}\text { Log real credit } \\
\text { to private } \\
\text { sector }\end{array}$ & $\begin{array}{c}\text { Log real } \\
\text { GDP }\end{array}$ & $\log C P I$ & $\begin{array}{l}\text { Log non- } \\
\text { interest } \\
\text { income }\end{array}$ & $\begin{array}{l}\text { Loan loss } \\
\text { provision }\end{array}$ & $\begin{array}{c}\text { Herfndahl } \\
\text { index }\end{array}$ & T-bill rate & Size & Liquidity & $\begin{array}{c}\text { Capitali- } \\
\text { zation }\end{array}$ \\
\hline Mean & 6.25 & 16.37 & 4.32 & 9.95 & 0.11 & 0.12 & 9.93 & 1.13 & -0.07 & -0.06 \\
\hline Median & 6.27 & 16.37 & 4.27 & 10.12 & 0.04 & 0.12 & 9.56 & 0.94 & -0.07 & -0.09 \\
\hline Maximum & 9.45 & 16.70 & 4.74 & 13.29 & 2.79 & 0.14 & 18.20 & 3.87 & 0.49 & 0.67 \\
\hline Minimum & -4.01 & 16.02 & 4.01 & 5.35 & -0.67 & 0.10 & 3.90 & -2.26 & -0.41 & -0.38 \\
\hline Std. Dev. & 1.66 & 0.22 & 0.23 & 1.69 & 0.30 & 0.01 & 4.43 & 1.45 & 0.17 & 0.13 \\
\hline Skewness & -1.04 & -0.05 & 0.42 & -0.40 & 4.43 & 0.23 & 0.37 & -0.23 & 0.30 & 3.04 \\
\hline Kurtosis & 8.00 & 1.77 & 1.90 & 2.74 & 32.96 & 2.71 & 2.00 & 2.50 & 2.78 & 16.74 \\
\hline Jarque-Bera & 282.70 & 14.76 & 18.32 & 6.86 & 9399.07 & 2.87 & 14.84 & 4.40 & 3.96 & 2172.81 \\
\hline Probability & 0.00 & 0.00 & 0.00 & 0.03 & 0.00 & 0.24 & 0.00 & 0.11 & 0.14 & 0.00 \\
\hline Observations & 231 & 231 & 231 & 231 & 231 & 231 & 231 & 231 & 231 & 231 \\
\hline Cross sections & 21 & 21 & 21 & 21 & 21 & 21 & 21 & 21 & 21 & 21 \\
\hline
\end{tabular}

Note: Annual data, sample: 2001 to 2011.

Source: Author's computations. 
Table I-B. Bank characteristics

\begin{tabular}{|c|c|c|c|}
\hline Item & 2001-03 & 2004--07 & 2008-11 \\
\hline \multicolumn{4}{|l|}{ Asset ratios } \\
\hline Top 5 banks assets/Total assets & 83.1 & 64.4 & 58.8 \\
\hline Bottom 5 banks assets/Total assets & 1.3 & 2.6 & 2.6 \\
\hline Medium size banks assets/Total assets & 15.6 & 33.0 & 38.6 \\
\hline Foreign banks assets/Total assets & 75.0 & 51.1 & 43.4 \\
\hline Domestic banks assets/Total assets & 24.0 & 43.8 & 45.7 \\
\hline Public banks assets/Total assets & 14.1 & 20.9 & 20.3 \\
\hline Private banks assets/Total assets & 84.8 & 74.0 & 68.7 \\
\hline \multicolumn{4}{|l|}{ Capitalization ratios } \\
\hline Top 5 banks capital/Top 5 banks assets & 3.0 & 6.0 & 8.9 \\
\hline Bottom 5 banks capital/Bottom 5 banks assets & 20.6 & 10.6 & 11.7 \\
\hline Medium size banks capital/Medium size banks assets & 12.3 & 12.0 & 11.8 \\
\hline Top 5 banks capital/Total assets & 2.3 & 3.9 & 5.3 \\
\hline Bottom 5 banks capital/Total assets & 0.2 & 0.3 & 0.3 \\
\hline Medium size banks capital/Total assets & 2.0 & 3.9 & 4.6 \\
\hline Foreign banks capital/Total assets & 3.4 & 4.9 & 4.5 \\
\hline Domestic banks capital/Total assets & 1.0 & 2.7 & 4.8 \\
\hline Public banks capital/Total assets & 0.4 & 1.3 & 2.2 \\
\hline Private banks capital/Total assets & 4.0 & 6.5 & 7.4 \\
\hline \multicolumn{4}{|l|}{ Liquidity ratios } \\
\hline Top 5 banks liquidy assets/Top 5 banks assets & 30.6 & 51.8 & 35.4 \\
\hline Bottom 5 banks liquidy assets/Bottom 5 banks assets & 43.6 & 43.3 & 40.4 \\
\hline Medium size banks liquidy assets/Medium size banks assets & 39.8 & 33.8 & 28.3 \\
\hline Top 5 banks liquid assets/Total assets & 23.1 & 33.4 & 20.8 \\
\hline Bottom 5 banks liquid assets/Total assets & 0.5 & 1.1 & 1.0 \\
\hline Medium size banks liquid assets/Total assets & 6.0 & 11.2 & 10.9 \\
\hline Foreign banks liquid assets/Total assets & 13.0 & 18.0 & 12.4 \\
\hline Domestic banks liquid aseets/Total assets & 16.7 & 27.6 & 20.0 \\
\hline Public banks liquid assets/Total assets & 8.5 & 13.8 & 8.5 \\
\hline Private banks liquid assets/Total assets & 21.2 & 32.0 & 24.4 \\
\hline
\end{tabular}

Source: Author's computations.

Table I-C. Correlation coefficients of the variables

\begin{tabular}{|c|c|c|c|c|c|c|c|c|c|c|}
\hline & $\begin{array}{c}\text { Log real credit } \\
\text { to private } \\
\text { sector }\end{array}$ & $\begin{array}{c}\text { Log real } \\
\text { GDP }\end{array}$ & $\log \mathrm{CPI}$ & $\begin{array}{l}\text { Log non- } \\
\text { interest } \\
\text { income }\end{array}$ & $\begin{array}{l}\text { Loan loss } \\
\text { provision }\end{array}$ & $\begin{array}{c}\text { Herfndah } \\
\text { l index }\end{array}$ & $\begin{array}{l}\text { T-bill } \\
\text { rate }\end{array}$ & Size & Liquidity & $\begin{array}{c}\text { Capitali- } \\
\text { zation }\end{array}$ \\
\hline Growth of real credit to private sector & 1 & & & & & & & & & \\
\hline Growth of real GDP & 0.10 & 1 & & & & & & & & \\
\hline Inflation & -0.17 & -0.68 & 1 & & & & & & & \\
\hline Log non-interest income & -0.10 & -0.20 & 0.34 & 1 & & & & & & \\
\hline Loan loss provision & -0.06 & -0.10 & 0.03 & -0.07 & 1 & & & & & \\
\hline Herfndahl index & 0.22 & 0.54 & -0.85 & -0.40 & -0.04 & 1 & & & & \\
\hline T-bill rate & -0.10 & -0.08 & 0.34 & 0.15 & -0.05 & -0.48 & 1 & & & \\
\hline Size & -0.06 & -0.08 & 0.14 & 0.88 & -0.14 & -0.16 & 0.06 & 1 & & \\
\hline Liquidity & -0.12 & 0.07 & -0.24 & 0.04 & 0.08 & 0.22 & -0.09 & 0.07 & 1 & \\
\hline Capitali-zation & 0.08 & 0.02 & -0.03 & -0.30 & 0.09 & 0.02 & -0.02 & -0.18 & -0.10 & 1 \\
\hline
\end{tabular}

Note: Annual data, sample: 2001 to 2011 .

Source: Author's computations. 


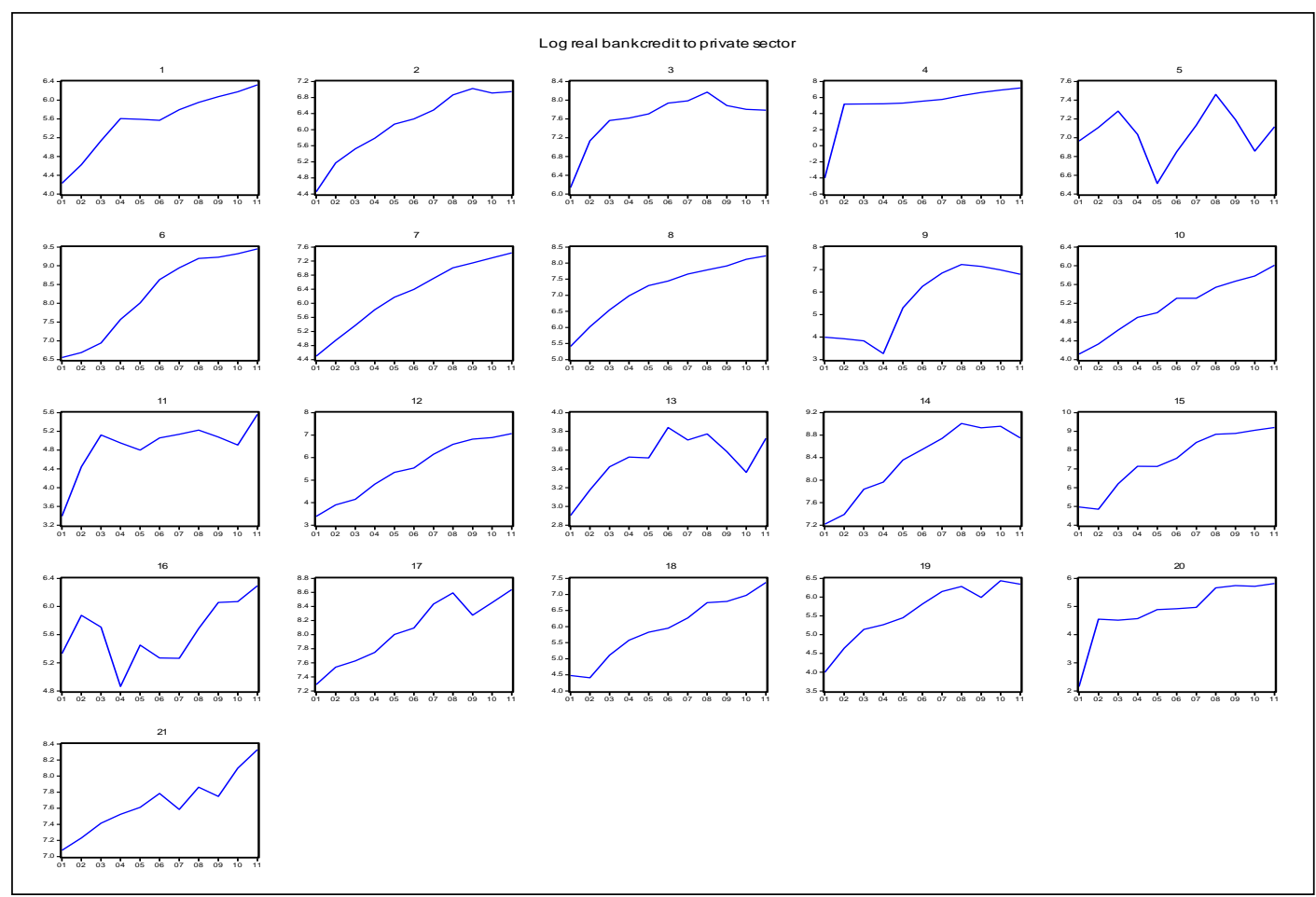

Figure I-A. Plot of real bank's credit to the private sector (in logarithms)

Source: Author's computation.

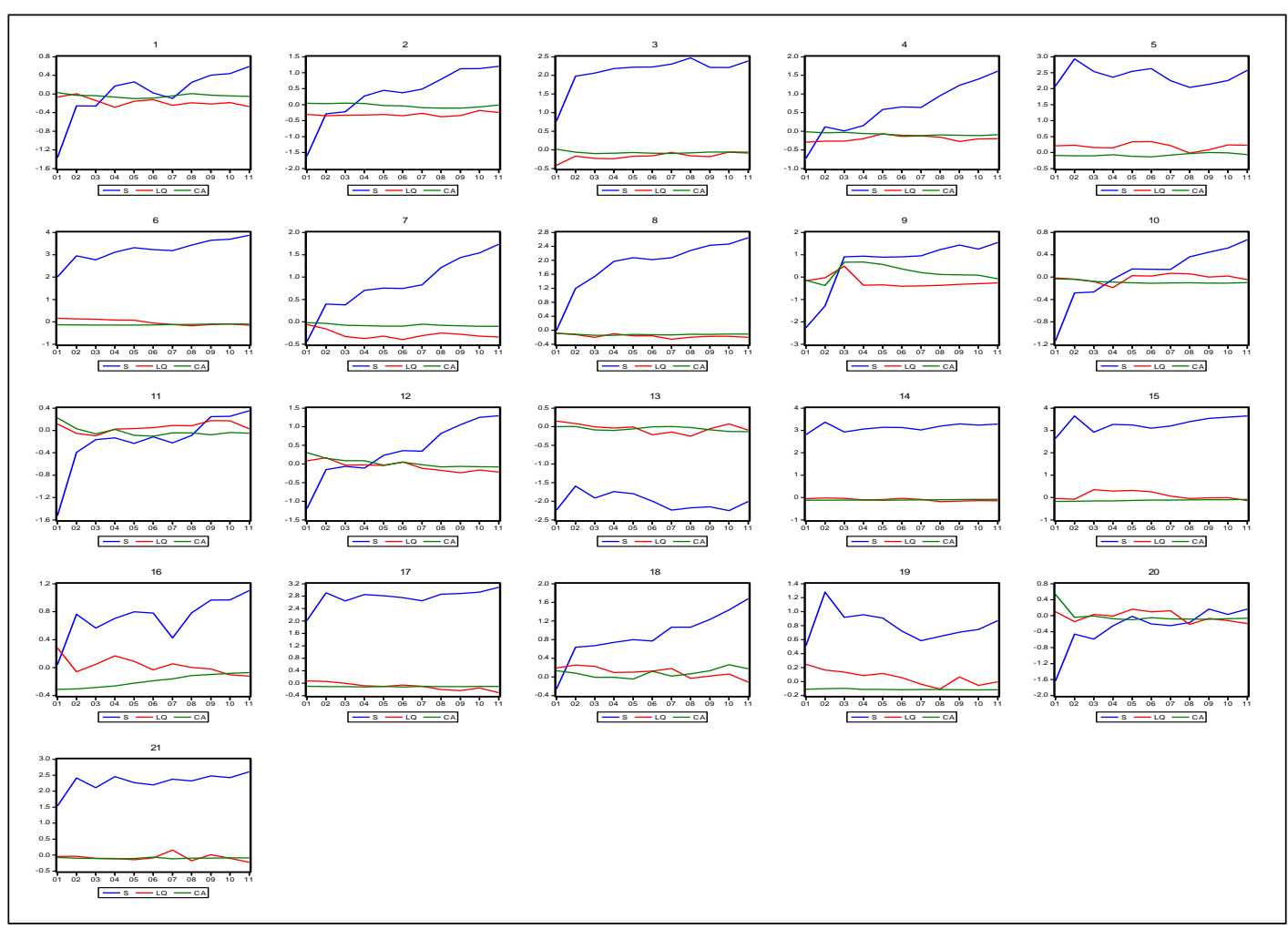

Figure I-B. Plot of bank's strength and size measures

Source: Author's computation. 


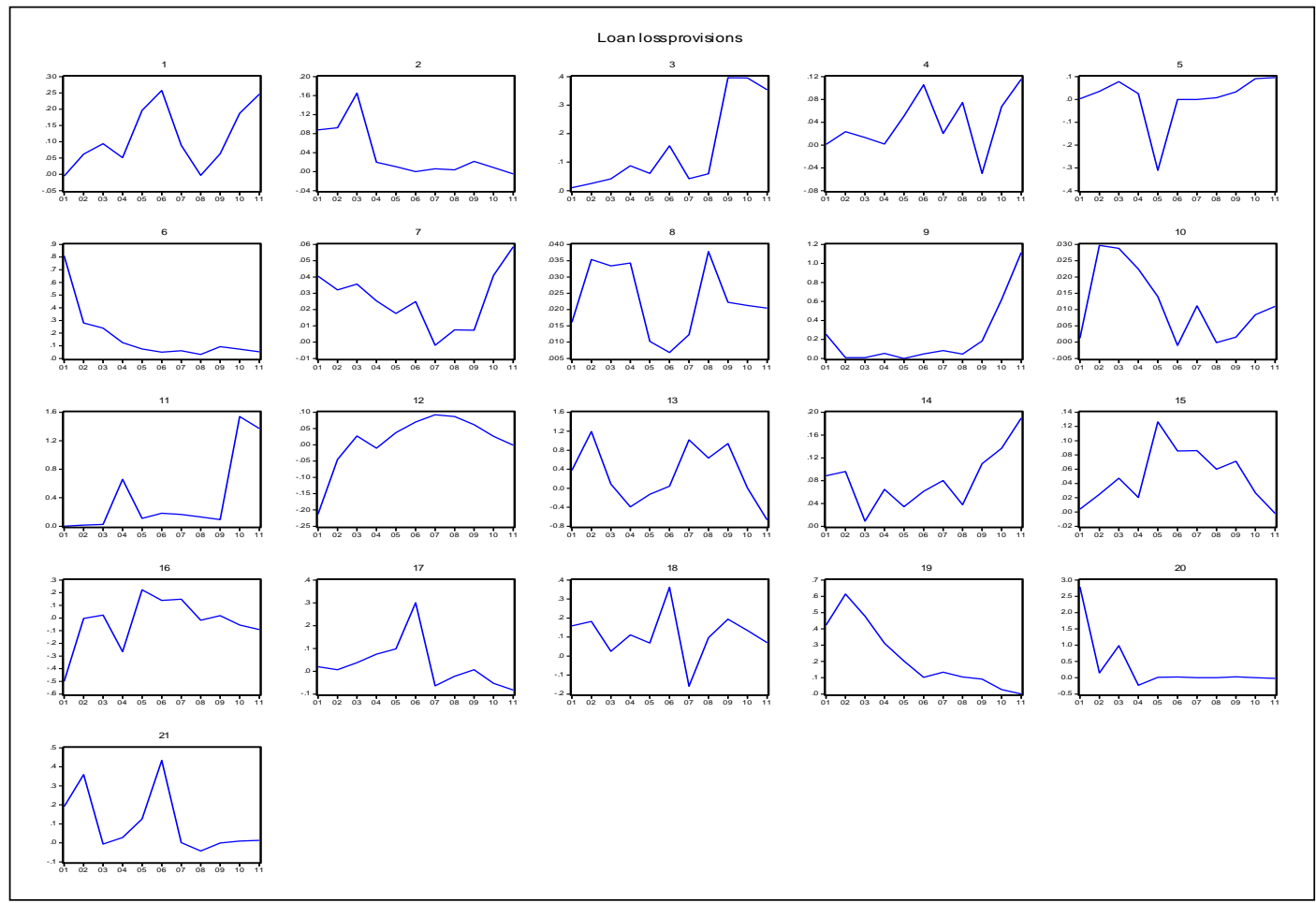

Figure I-C. Bank’s loan loss provisions

Source: Author's computation.

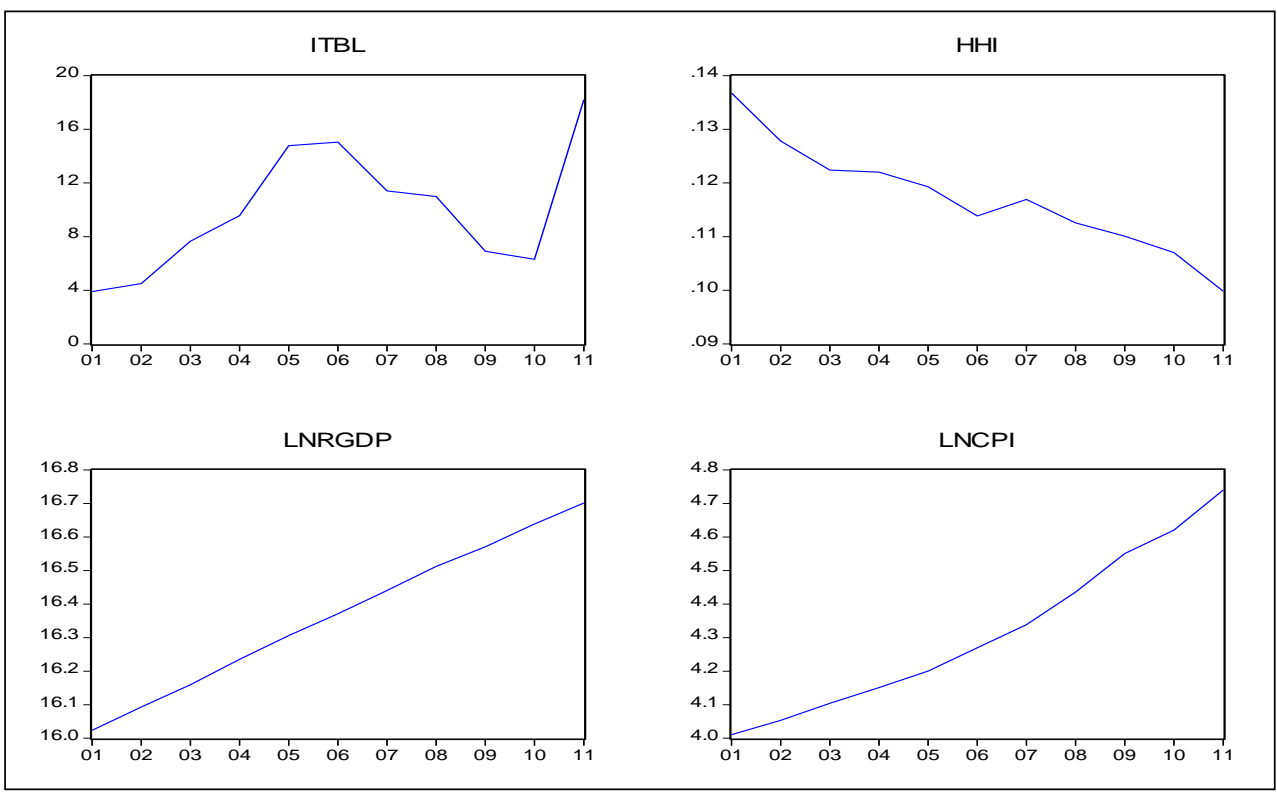

Figure I-D. Trends in T-bill rate, competition measure, log real GDP and log CPI

Source: Author's computations. 


\section{Appendix II: Additional regression results}

Table II-A: Results of the general model (all variables)

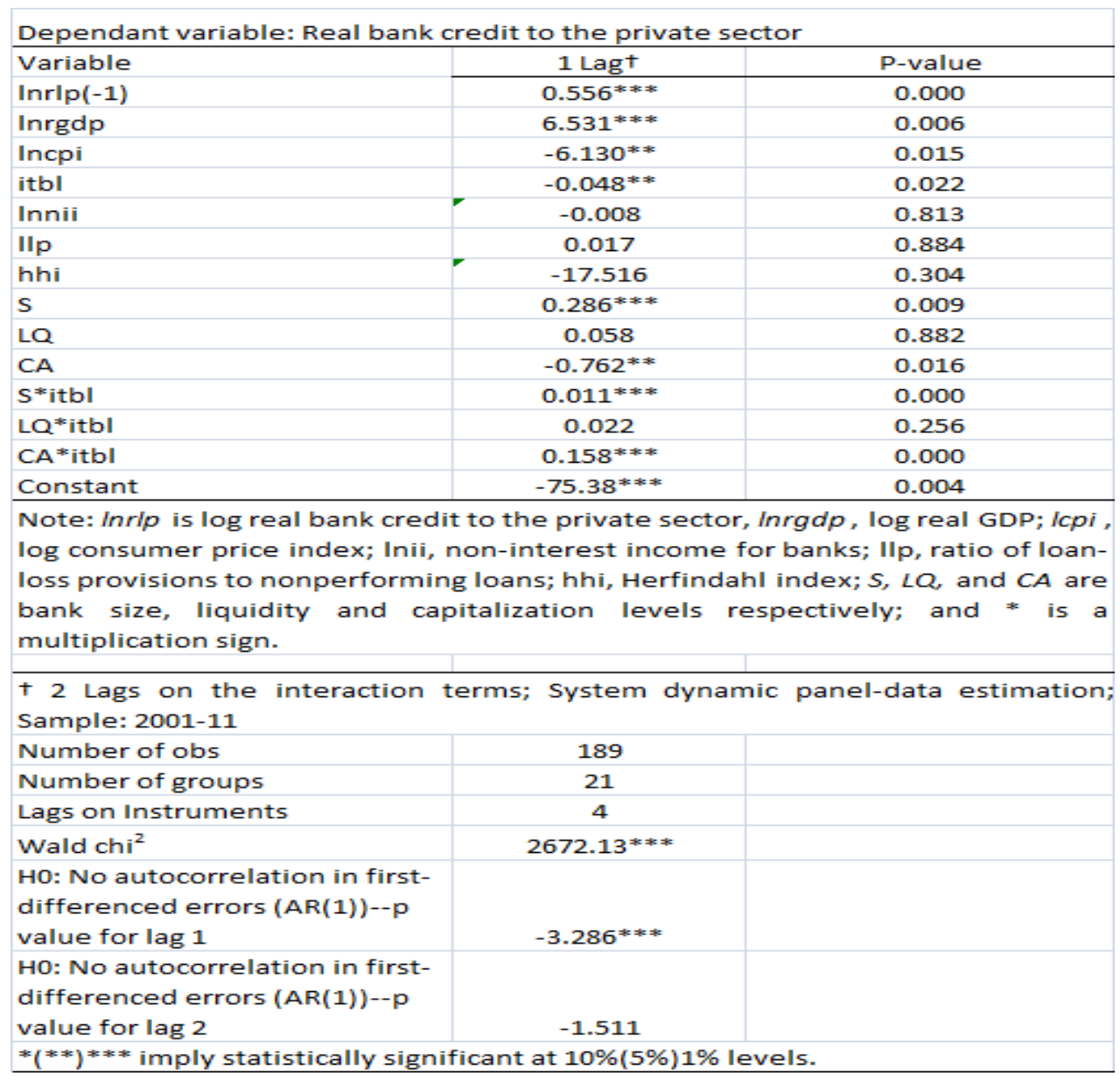

Source: Author's computations. 
Table II-B. Fixed and random effects and dynamic panel data estimation results

\begin{tabular}{|c|c|c|c|}
\hline \multicolumn{4}{|c|}{ Dependant variable: Real bank credit to the private sector } \\
\hline \multirow{3}{*}{ Variable } & {$[1]$} & [2] & {$[3]$} \\
\hline & Fixed-Effects & Random-Effects & $\begin{array}{l}\text { Arellano-Bond } \\
\text { Dynamic Panel- } \\
\text { Data (One-step) }\end{array}$ \\
\hline & 1 Lag $^{\dagger}$ & 1 Lag $^{\dagger}$ & 1 Lag $^{\dagger}$ \\
\hline Inrlp(-1) & $0.541^{* * *}$ & $0.596^{* * *}$ & $0.386^{* * *}$ \\
\hline Inrgdp & $4.916^{* *}$ & $4.413^{* *}$ & $5.748^{* * *}$ \\
\hline Incpi & $-4.023^{* *}$ & $-3.832^{* *}$ & $-4.258^{* * *}$ \\
\hline itbl & $-0.026^{* *}$ & $-0.026^{* *}$ & $-0.026^{* *}$ \\
\hline s & $0.277^{* * *}$ & $0.316^{* * *}$ & 0.179 \\
\hline LQ & -0.322 & $-0605^{* *}$ & -013 \\
\hline CA & -0.373 & -0.344 & $-0.616^{* *}$ \\
\hline S*itbl & $0.010^{* * *}$ & $0.009^{* * *}$ & $0.011^{* * *}$ \\
\hline LQ*itbl & 0.021 & 0.011 & 0.007 \\
\hline CA*itbl & $0.125^{* * *}$ & $0.080^{* * *}$ & $0.139^{* * *}$ \\
\hline Constant & $-60.20^{* *}$ & $-53.218^{* *}$ & $-71.713^{* * *}$ \\
\hline
\end{tabular}

Note: Inrlp is log real bank credit to the private sector, Inrgdp, log real GDP; Icpi, log consumer price index; $S, L Q$, and $C A$ are bank size, liquidity and capitalization levels respectively; and ${ }^{*}$ is a multiplication sign.

† 2 Lags on the interaction terms; Sample: 2001-11

Number of obs

189

Number of groups

21

$\mathrm{F}(9,20) /$ Wald $\mathrm{Chi}^{2}$

Overall $R^{2}$

rho $596.9^{* * *}$ 0.970

HO: No autocorrelation in first-

0.474 differenced errors $(\operatorname{AR}(1))--p$ value for lag 1 HO: No autocorrelation in firstdifferenced errors $(A R(1))--p$ value for lag 2 $*(* *)^{* * *}$ imply statistically significant at $10 \%(5 \%) 1 \%$ levels.

Source: Author's computations.

\section{Copyrights}

Copyright for this article is retained by the author(s), with first publication rights granted to the journal.

This is an open-access article distributed under the terms and conditions of the Creative Commons Attribution license which permits unrestricted use, distribution, and reproduction in any medium, provided the original work is properly cited. 